\title{
PROCESS EFFICIENCY AND ENERGY CONSUMPTION DURING THE EXTRUSION OF POTATO AND MULTIGRAIN FORMULATIONS
}

\author{
Arkadiusz Matysiak $^{\mathrm{a}}$, Agnieszka Wójtowicz ${ }^{\mathrm{b}^{*}}$, Tomasz Oniszczuk ${ }^{\mathrm{b}}$ \\ ${ }^{\text {a }}$ POL-FOODS Sp. z o.o., Prostki, Poland \\ ${ }^{\mathrm{b}}$ Department of Thermal Technology and Food Process Engineering, \\ University of Life Sciences in Lublin, Poland \\ ${ }^{*}$ Corresponding author: e-mail: agnieszka.wojtowicz@up.lublin.pl
}

\begin{tabular}{|c|c|}
\hline ARTICLE INFO & ABSTRACT \\
\hline $\begin{array}{l}\text { Article history: } \\
\text { Received: April } 2018 \\
\text { Received in the revised form: } \\
\text { May } 2018 \\
\text { Accepted: June } 2018 \\
\end{array}$ & $\begin{array}{l}\text { The aim of the research was to determine the effect of extrusion } \\
\text { conditions (various moisture content of raw materials and screw } \\
\text { rotation speed), as well as the effect of recipe composition on the } \\
\text { process efficiency and the energy consumption during treatment of } \\
\text { potato and multigrain products. The efficiency of the extrusion pro- }\end{array}$ \\
\hline $\begin{array}{l}\text { Key words: } \\
\text { extrusion, } \\
\text { pellets, } \\
\text { extrudate, } \\
\text { multigrain, } \\
\text { efficiency, } \\
\text { SME }\end{array}$ & $\begin{array}{l}\text { cess (Q) was determined by the mass of the product obtained at } \\
\text { a given time for all prepared raw material mixtures and the process } \\
\text { parameters used, while the specific mechanical energy demand was } \\
\text { determined using the SME index. The obtained results allow to con- } \\
\text { clude that the level of raw materials moisture content had a greater } \\
\text { impact on the efficiency and energy consumption of the extrusion } \\
\text { process than the variable screw speed during the treatment. The effi- } \\
\text { ciency of the process increased with the increasing moisture of the } \\
\text { tested compositions, while a decrease in the requirements of SME was } \\
\text { observed. The use of differentiated raw material compositions also } \\
\text { influenced the Q and SME values determined during the tests. }\end{array}$ \\
\hline
\end{tabular}

\section{Introduction}

Various raw materials are used for the production of extrudates. The bases are cereals, legume seeds and tuberous plants. It uses flours, grits, starch, and above all, corn products, wheat flour and potato products. The potato raw materials include:

- potato starch (the basic component of extruded pellets),

- ground potato granules or grits (give a characteristic aftertaste),

- potato flakes (structure-forming agent, improves the flexibility of the dough),

- potato starch modified chemically or physically (optional).

Potato ingredients in the form of native starch or modified potato products are used to improve the structure and texture when expanding the pellet extrudates (Kraus et al., 2014). Potato extrudates, which can be obtained from potato flakes and potato grits, have a similar expansion rate, but a completely different texture. The addition of potato grits makes the products' structure smoother, darker in color and crunchier. Potato raw materials, such as flakes or grits, require a relatively low processing temperature, the so-called cold extrusion at $50-55^{\circ} \mathrm{C}$, because the initial treatment, as drum drying, is responsible for partial gelatini- 
zation of starch, so these components can be processed in a low temperature (BastosCardoso et al., 2007; van der Sman and Broeze, 2013). Depending on the intensity of shearing, part of the native starch can gelatinize in the extruder. The snack pellets are in the glassy state, and are thus shelf-stable. In the case of potato ingredients extruder is working as a former to heat and form viscous dough outcoming from the forming die (Cheyne et al., 2005). Expansion to the final RTE (ready-to-eat) snacks commonly occurs by immersion of the pellets in frying oil, by microwave heating or roasting with hot air (Kraus et al., 2013; van der Sman and Broeze, 2013). This method is widely used for snack pellets processing because it allows obtaining a very good product quality as high crispness, low density and high expansion index (Nath et al., 2007). The profile of extrusion screw dedicated for potato raw materials is characterized by short geometry, with low rotations during processing (range of 25-40 rpm) to avoid overheating of starchy materials and direct expansion of pellets (Juśko et al., 2009). Using the same processing parameters, changing only the composition of the mixture, it is possible to achieve products with different quality characteristics. Changes include product color, expansion intensity, shape, crunchiness, bulk density, oil absorption and manufacturing costs (Moscicki, 2011; Nath et al., 2007).

The total starch content in the recipe should be around $50 \%$. As a result, the products in the form of pellets after frying become crispy. Potato snack pellets in their composition contain mainly potato starch, grits and flakes and salt, and final products are characterized by a crunchy texture and potato flavor (Gutiérrez et al., 2017). An important addition to the production of pellets is salt $(\mathrm{NaCl})$, which improves the taste, affects the formation of a porous structure and crunchy texture of the snacks. The extrudates and snack pellets produced from cereal flours: wheat, corn and rice are also important part of the market. The main difference in the extrusion process between potato and cereal products is the intensity of gelatinization of the above-mentioned raw materials: in the case of potato raw materials this level is significantly lower because of the initial pre-treatment, especially if dry potatobased ingredients are used (Cheyne et al., 2005).

The extrusion-cooking technique is widely used in the production of extrudates from cereals, pseudo-cereals or their derivatives. Multigrain products are mainly made of maize, wheat, rice, barley, oats, quinoa; they are characterized by an increased content of fiber and protein and reduced salt content. Recently, some fruits, vegetables, vitamins and minerals or flavoring substances are added to cereal raw materials mainly to increase the attractiveness of final products. Both the selection of raw materials and the conditions of the technological processing have an impact on the efficiency, energy consumption and stability of extruded products processing (Majzoobi and Farahnaky, 2011).

\section{Objective, scope and methods of research}

The purpose of the work was to determine the effect of the extrusion process conditions (various moisture content of raw materials and screw speed during production) on process efficiency and mechanical energy requirements during production of extrudates from various recipes based on potato raw materials and multigrain mixture as half products for snacks. The most popular in the industry are potato pellets but since last year there has been a huge interest in multigrain pellets from the market. So presented work is an introduction for developing the best processing practice for new types of products in a laboratory scale. 
Raw materials used in the research were obtained from domestic and foreign suppliers. The materials included potato components as: potato starch, potato flakes, modified starch (Emsland, Emlichheim, Germany), salt, and cereal components as: maize flours (Pol-Foods, Prostki, Poland), wheat flour (Młyn Szczepanki, Łasin, Poland), rice flour (Młyn Niedźwiady, Niedźwiady, Poland), oat flour (Melvit, Warsaw, Poland) and quinoa (Agnex, Białystok, Poland).

Two compositions of mixtures based on potato and cereal raw materials were prepared. The recipe based on potato ingredients consisted of: potato starch $-63 \%$, potato flakes $30 \%$, modified potato starch $-5 \%$, salt $-2 \%$. The multigrain composition was prepared in the following proportions of ingredients: maize flour $-47.5 \%$, wheat flour $-28 \%$, rice flour $-15 \%$, oat flour $-5 \%$, sugar $-1.5 \%$, salt $-1 \%$, vegetable oil $-0.5 \%$. Samples of $10 \mathrm{~kg}$ of dry ingredients were prepared by weighting components using laboratory scale WPT 150 (Radwag, Poland) with accuracy of $0.02 \mathrm{~kg}$. The mixtures of raw materials according to developed recipes were moistened by spraying the dry ingredients with the calculated amount of tap water based on the initial moisture of blends (Kręcisz, 2016) to 32, 33 and $34 \%$ of final moisture content during continuous mixing in a laboratory ribbon mixer by $10 \mathrm{~min}$. Blends were processed using a single-screw extruder S45-12 ICHEMAD PROFARB (Metalchem, Gliwice, Poland) to form snack pellets cut off at the forming head with an annular die with a slot width $25 \mathrm{~mm}$ and gap having a thickness of $1.0 \mathrm{~mm}$ using different screw speeds $(20,40,60 \mathrm{rpm})$. The $\mathrm{L} / \mathrm{D}=18 / 1$ configuration was used, temperatures of $45 / 55 / 45^{\circ} \mathrm{C}$ were applied during the extrusion of potato raw materials with efficient cooling of the special design of the last barrel section (Juśko et al. 2009) using controlled flow of chilled water (Tempro Primus C90 chiller, Wittmann, Wien, Austria), respectively on the first/second section and the forming die, in the case of multigrain composition the temperatures were $60 / 145 / 100^{\circ} \mathrm{C}$, respectively. The ring shaped extrudates with the moisture of $22-24 \%$ after processing were dried at $55-60^{\circ} \mathrm{C}$ for $6 \mathrm{~h}$ to the final moisture content not exceeding $11 \%$ in a belt dryer (Climatic Chamber with a Dryer HPP 260, Donserv, Warszawa, Poland).

Evaluation of the extrusion process efficiency was carried out by determining the mass of produced potato and multigrain extrudates at a given time for prepared compositions and all the process parameters used (screw speed and mixture moisture content). The efficiency of the $Q$ process was determined according to the formula (Kręcisz, 2016; Bouasla et al., 2017):

$$
Q=\frac{m}{t}\left(\mathrm{~kg} \cdot \mathrm{h}^{-1}\right)
$$

where:

$$
\begin{array}{ll}
Q & - \text { process efficiency, } \\
m & - \text { mass of the extrudate, }(\mathrm{kg}) \\
t & - \text { testing time, }(\mathrm{h})
\end{array}
$$

Taking into account the specification of the motor installed in the S45-12 extruder, determining the engine load and the efficiency obtained in individual tests, the values were converted into the specific mechanical energy consumption $(S M E)$ according to the formula given by Ryu and $\mathrm{Ng}(2001)$ : 


$$
S M E=\frac{n}{N} \times \frac{L}{100} \times \frac{P}{Q}\left(\mathrm{kWh}^{-1}\right)
$$

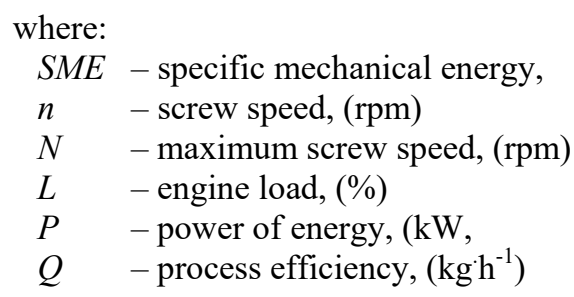

The obtained results were analyzed using ANOVA analysis of variance in terms of the effect of the level of raw materials moisture content and variable screw speeds during the production on the efficiency and energy consumption of the snack pellets extrusion-cooking process as average results from three production cycles. The response surface method (RSM) was used to create $3 \mathrm{~W}$ surface charts to explore the effect of operating conditions (the independent factors) on the tested variables and to obtain an optimal response with the distance-weighted least squares smoothing using O Dell Statistica 13.1 software (Dell Inc., Tulsa, USA).

\section{Results and analysis}

Response surface methodology (RSM) is an important tool in the process and product improvement. RSM is a collection of experimental design and optimization techniques that enables the experimenter to determine the relationship between the response and the independent variables (Altan et al., 2008). Kaur et al., (2015) tested possibilities of multigrain compositions for processing of breakfast cereal using an extrusion technology. They found the application of the Response Surface Methodology (RSM) as a useful method for optimizing composition of ingredients i.e. wheat, rice and maize as well as process parameters. In their research the RSM involved design of experiments, selection of levels of variables in experimental runs, fitting mathematical models and finally selecting variables' level by optimizing the responses and this research has been done on the extrusion based products from various cereals, pulses, vegetables and fruits and their combinations. So, the experimental results of the processing efficiency during the extrusion-cooking of two tested compositions were used for the RSM modelling of relationships between processing variables screw speed and moisture content, to achieve response with the predicted values (Table 1). From the response of the effect of two processing factors on the processing efficiency the greatest value of the tested parameter was found if $60 \mathrm{rpm}$ and $34 \%$ of moisture content was applied during the processing. 
Process efficiency...

Table 1.

Multiple regression equations and regression coefficient of process efficiency and specific energy consumption models for various compositions of raw materials

\begin{tabular}{|c|c|c|c|}
\hline Composition & $\begin{array}{l}\text { Dependent } \\
\text { variable }\end{array}$ & Regression equation & $\mathrm{R}^{2}$ \\
\hline \multirow{2}{*}{ Potato } & $Q$ & $\begin{array}{l}Q=779.807-47.1 * M C-0.635 * S S+0.722 * M C^{2}+0.023 * M C^{*} S S- \\
0.0005 * S S^{2}\end{array}$ & 0.896 \\
\hline & $S M E$ & $\begin{array}{l}S M E=-8.362+0.504 * M C+0.039 * S S-0.008 * M C^{2}-0.001 * M C * S S- \\
1.862 \mathrm{E}-5 * S S^{2}\end{array}$ & 0.949 \\
\hline \multirow{2}{*}{ Multigrain } & $Q$ & $\begin{array}{l}Q=457.543-27.589 * M C-0.495 * S S+0.428 * M C^{2}+0,0146 * M C * S S \\
+0.0007 * S S^{2}\end{array}$ & 0.920 \\
\hline & $S M E$ & $\begin{array}{l}S M E=-3.098+0.186 * M C+0.044 * S S-0.003 * M C^{2}-0.001 * M C * S S- \\
2,447 \mathrm{E}-5 * S S^{2}\end{array}$ & 0.962 \\
\hline
\end{tabular}

The results of process efficiency during processing of potato composition are presented in Fig. 1a. The lowest efficiency was observed during treatment of components at screw speed lower than $40 \mathrm{rpm}$ and the moisture content at $32 \%$. For potato composition extrusion efficiency increased significantly $(p=0.000, \mathrm{r}=0.71)$ with the increasing moisture content of raw materials but the effects of screw speed were not significant (Table 2).
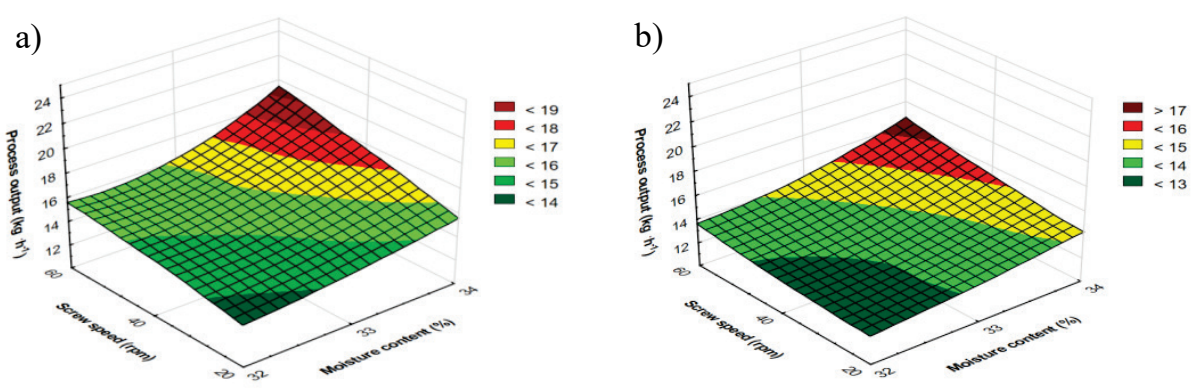

Figure 1. Effect of processing variable conditions on processing efficiency during the extrusion of various raw materials: a) potato composition, b) multigrain composition

Moreover, the effect of variable processing conditions on the efficiency during treatment of multigrain composition was also evaluated. The results of the RSM presented in Fig. 1b suggest similar trends as has been found for potato composition, but processing of cereal raw materials showed lower values of pellets extrusion efficiency. The lowest efficiency was found if the low moisture content (32\%) and low screw speed (20 rpm) were used. Regression and variance analyses showed significant effect of the initial moisture content of raw materials $(p=0.000, \mathrm{r}=0.95)$ than the screw speed effect on the processing efficiency of multigrain composition (Table 2). Comparison of the results of the process efficiency of both potato and multigrain compositions showed that the high values of effi- 
ciency during processing were determined by a high initial moisture content of raw materials but the screw speed was found to be less important in this case because of lower values of $F$ test. It could be related to the viscosity reduction of the treated materials because the water added acts as a lubricant, facilitating material flow through the extruder barrel and reducing the mechanical shearing impact (Camacho-Hernández et al., 2014). During the extrusion-cooking process even small differences in moisture of the treated material may have an effect on the processing efficiency so the proper level of moistening should involve the expected quality characteristics of final products as well as production yield. To achieve the proper processing and desirable properties of snack pellets the moisture content should range from 31 to $37 \%$ dependently on the recipe used as well as the extruder and screw configuration (Kraus et al., 2013; Moscicki, 2011). Analyzing the effect of composition of the tested mixtures lower efficiency of the multigrain composition may be observed which may result from a higher gelatinization temperature of cereals than potato ingredients. The higher temperature profile required for the treatment generates the higher viscosity of the treated materials and impeded material flow through the extruder can affect the lower efficiency of the process.

The effect of processing conditions on specific mechanical energy consumption was also tested. The results of RSM for potato composition showed the highest SME if the lowest initial moisture content and the highest screw speed were applied during processing (Fig. 2a). The lowest energy consumption was observed at the lowest screw speed if the high level of moisture was used. Regression coefficients and analysis of variance indicated more significant effect of the screw speed $(p=0.000, \mathrm{r}=0.793)$ than the moisture content.
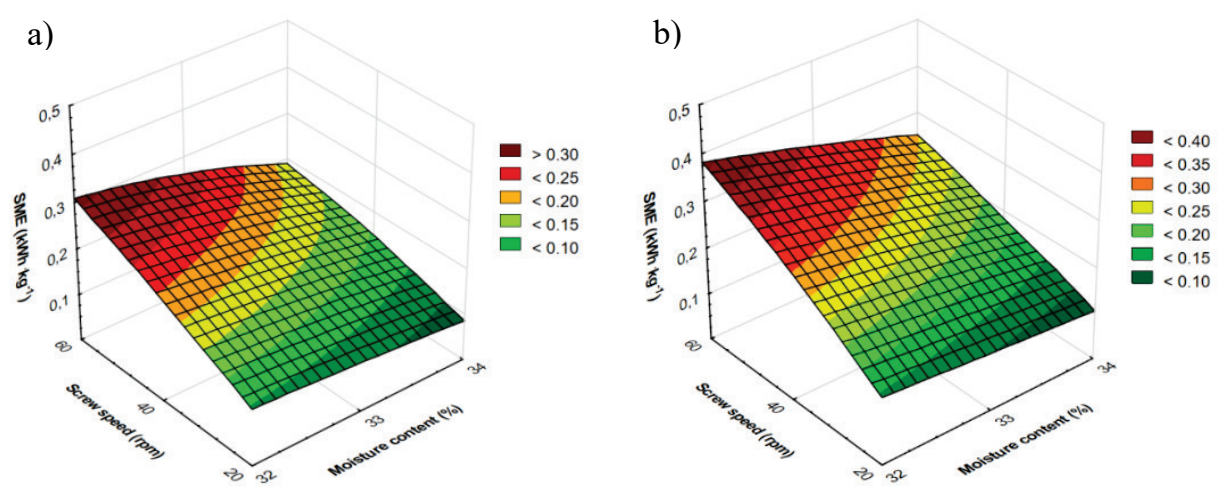

Figure 2. Effect of processing variable conditions on specific mechanical energy requirements during the extrusion of various formulations of raw materials: a) potato composition, b) multigrain composition

Similar observations have been made when multigrain composition was tested. In this case the effect of screw speed $(p=0.000, \mathrm{r}=0.80)$ was again more significant than the effect of moisture content, what is indicated by higher values of $F$ test (Table 2). Figure $2 \mathrm{~b}$ shows the response surface graph of SME depending on the temperature and screw speed during 
Process efficiency...

processing of multigrain composition. The energy consumption was higher during processing of cereal raw materials, because the higher $S M E$ usually is the result the greater degree of starch gelatinization, as reported by Meng et al., (2010). The effect of the moisture level depends on the processing equipment and conditions applied. Blicharz-Kania et al., (2015) tested influence of the moisture content of grain and size of the working gap on the flaking energy and they found that the moisture influenced the energy consumption of the process. It was found out that the raw material moisture significantly affects the flaking energy. The highest values of energy were reported at the grain moisture of $18 \%$, whereas the least energy was necessary for flaking of raw material with $26 \%$ moisture.

Table 2.

Results of analysis of variance of the effect of processing conditions and raw materials composition on process efficiency and energy consumption during the extrusion (level of significance 0.05)

\begin{tabular}{|c|c|c|c|c|c|c|c|c|c|c|}
\hline $\begin{array}{l}\text { Independent } \\
\text { variable }\end{array}$ & $\begin{array}{l}\text { Composi- } \\
\text { tion }\end{array}$ & $\begin{array}{c}\text { Dependent } \\
\text { variable }\end{array}$ & $\begin{array}{l}\text { Sum of } \\
\text { Square } \\
\text { Effect }\end{array}$ & $\begin{array}{c}\mathrm{df} \\
\text { Effect }\end{array}$ & $\begin{array}{c}\text { Mean } \\
\text { Square } \\
\text { Effect }\end{array}$ & $\begin{array}{c}\text { Sum of } \\
\text { Square } \\
\text { Error }\end{array}$ & $\begin{array}{c}\mathrm{df} \\
\text { Error }\end{array}$ & $\begin{array}{c}\text { Mean } \\
\text { Square } \\
\text { Error } \\
\end{array}$ & $F$ test & $p$ \\
\hline \multirow{4}{*}{$\begin{array}{l}\text { Moisture } \\
\text { content } \\
(\%)\end{array}$} & \multirow{2}{*}{ potato } & $Q$ & 41.849 & 2 & 20.924 & 35.204 & 24 & 1.466 & 14.265 & $0.000 *$ \\
\hline & & $S M E$ & 0.026 & 2 & 0.013 & 0.105 & 24 & 0.004 & 3.019 & 0.067 \\
\hline & \multirow{2}{*}{ multigrain } & $Q$ & 28.231 & 2 & 14.115 & 14. & 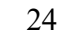 & 0.621 & 22.726 & $0.000^{*}$ \\
\hline & & $S M E$ & 0.035 & 2 & 0.017 & 0.174 & 24 & 0.007 & 2.430 & 0.109 \\
\hline \multirow{4}{*}{$\begin{array}{l}\text { Screw } \\
\text { speed } \\
(\mathrm{rpm})\end{array}$} & \multirow{2}{*}{ potato } & $Q$ & 31.209 & 2 & 15.604 & 45.844 & 24 & 1.910 & 8.169 & $0.002 *$ \\
\hline & & $S M E$ & 0.099 & 2 & 0.049 & 0.031 & 24 & 0.001 & 37.580 & $0.000 *$ \\
\hline & \multirow{2}{*}{ multigrain } & $Q$ & 13.298 & 2 & 6.649 & 29.840 & 24 & 1.243 & 5.347 & $0.012 *$ \\
\hline & & $S M E$ & 0.167 & 2 & 0.083 & 0.041 & 24 & 0.001 & 47.976 & $0.000 *$ \\
\hline
\end{tabular}

* marks signifficant effect at 0.05

Marks (2010) found an opposite tendency for the grinding process and increasing the initial moisture content from 10 to $18 \%$ increased the energy requirements for triticale and rye. Some authors observed that raw materials screw speed and moisture content significantly affected the $S M E$ values of the expanded extrudates (Meng et al., 2010; Ruiz-Ruiz et al., 2008). Results presented by da Silva et al. (2014) reported the values of SME of the extruded products processed under experimental conditions (moisture 11-21\%, screw speed 333-378 rpm) and it was shown that none of the variables studied (screw speed, moisture and bean level) significantly influenced the $S M E$ values. Moreover, the results indicated that the $S M E$ did not have any significant correlation with the other variables. 


\section{Conclusions}

Based on the presented research the following conclusions have been found:

1. Processing of cereal raw materials composition showed lower values of extrusion efficiency than reported for potato raw materials.

2. Results of $S M E$ indicated the more important effect of screw speed than moisture content applied during processing, both for potato and multigrain compositions tested.

\section{References}

Altan, A., McCarthy K.L., Maskan M. (2008). Extrusion cooking of barley flour and process parameter optimization by using response surface methodology. Journal of the Science of Food and Agriculture, $88,1648-1659$.

Bastos-Cardoso, I., Zazueta-Morales, J.J., Martinez-Bustos, E., Kil-Chang, Y. (2007). Development and characterization of extruded pellets of whole potato (Solanum tuberosum L.) flour expanded by microwave heating. Cereal Chemistry, 84(2), 137-144.

Blicharz-Kania, A., Andrejko, D., Ślaska-Grzywna, B., Starek, A., Szejgiec, P., Krzaczek, P. (2015). The influence of moisture content of barley on the flaking process. Agricultural Engineering, 1(153), 5-14.

Bouasla, A., Wójtowicz, A., Juśko, S., Zidoune, M.N. (2017). Energy consumption and process efficiency as affected by extrusion-cooking conditions and recipe formulation during the production of gluten-free rice-legumes products, Agricultural Engineering, 21(1), 39-46.

Camacho-Hernández, I.L., Zazueta-Morales, J.J., Gallegos-Infante, J.A., Aguilar- Palazuelos, E., Rocha-Guzmán, N.E., Navarro-Cortez, R.O., Jacobo-Valenzuela, N., Gómez-Aldapa, C.A. (2014). Effect of extrusion conditions on physicochemical characteristics and anthocyanin content of blue corn third-generation snacks. CyTA Journal of Food, 12(4), 320-330.

Cheyne, A., Barnes, J., Gedney, S., Wilson, D.I. (2005). Extrusion behaviour of cohesive potato starch pastes: II. Microstructure-process interactions. Journal of Food Engineering, 66(1), 13-24.

da Silva, E.M.M., Ascheri, J.L.R., de Carvalho, C.W.P., Takeiti, C.Y., de J. Berrios, J. (2014). Physical characteristics of extrudates from corn flour and dehulled carioca bean flour blend. $L W T$ Food Science and Technology, 58, 620-626.

Gutiérrez, J., Catalá-Civera, J., Bows, J., Pẽnaranda-Foix, F. (2017). Dynamic measurement of dielectric properties of food snack pellets during microwave expansion. Journal of Food Engineering, 202, 1-8.

Juśko, S., Mościcki, L., Wójtowicz, A. (2009). Cooling-forming section. Design Patent PL64690Y1. Patent Office Bulletin (BUP), 2(195), 25.

Kaur, G.J., Rehal, J., Singh, B., Singh, A. K., Kaur, A.(2015). Development of multigrain breakfast cereal using extrusion technology. Asian Journal of Dairy and Food Research, 34(3), 219-224.

Kraus, S., Schuchmann, H.P., Gaukel, V. (2014). Factors influencing the microwave induced expansion of starch-based extruded pellets under vacuum. Journal of Food Process Engineering, 37, 264-272.

Kraus, S., Sólyom, K., Schuchmann, H.P., Gaukel, V. (2013). Drying kinetics and expansion of nonpredried extruded starch-based pellets during microwave vacuum processing. Journal of Food Process Engineering, 36, 763-773.

Kręcisz, M. (2016). Energy consumption during production of corn extrudates in relation to the process parameters. Agriculture Engineering, 20(7), 195-203.

Majzoobi, M., Farahnaky, A. (2011). Comparison of the effects of extrusion cooking on some cereal starches. International Journal of Food Engineering, 6(3), 2. Doi:10.2202/1556-3758.1456.

Marks, N. (2010). Wpływ wilgotności na zużycie energii bezpośredniej w procesie rozdrabniania ziarna żyta i pszenżyta. Inżynieria Rolnicza, 7(125), 125-130. 
Process efficiency...

Meng, X., Threinen, D., Hansen, M., Driedger, D. (2010). Effects of extrusion conditions on system parameters and physical properties of a chickpea flourbased snack. Food Research International, 43, 650-658.

Moscicki, L. (2011). Snack pellets. In: Extrusion-Cooking Techniques, Wiley VCH, Germany, 8189.

Nath, A., Chattopadhyay, P.K., Majumdar, G.C. (2007). High temperature short time air puffed ready-to-eat (RTE) potato snacks: process parameter optimization. Journal of Food Engineering, 80, 770-780.

Ruiz-Ruiz, J., Martínez-Ayala, A., Drago, S., González, R., Betancur-Ancona, D., Chel-Guerrero, L. (2008). Extrusion of a hard-to-cook bean (Phaseolus vulgaris L.) and quality protein corn (Zea mays L.) flour blend. LWT - Food Science and Technology, 41, 1799-1807.

Ryu, G. H., Ng, P. K. (2001). Effect of selected process parameters on expansion and mechanical properties of wheat flour and whole cornmeal extrudates. Starch/Stärke, 53, 147-154.

Wójtowicz, A. Zalewska-Korona, M., Jabłońska-Ryś, E., Skalicka-Woźniak, K., Oniszczuk, A. (2018). Chemical characteristics and physical properties of functional snacks enriched with powdered tomatoes. Polish Journal of Food and Nutrition Sciences, 68(3), 251-261.

van der Sman, R.G.M., Broeze, J. (2013). Structuring of indirectly expanded snacks based on potato ingredients: A review. Journal of Food Engineering, 114(4), 413-425.

\section{WYDAJNOŚĆ I ENERGOCHLONNOŚĆ PROCESU EKSTRUZJI MIESZANEK ZIEMNIACZANYCH ORAZ WIELOZBOŻOWYCH}

Streszczenie. Celem badań było określenie wpływu warunków obróbki mieszanki podczas procesu ekstruzji (zróżnicowana wilgotność mieszanek surowcowych i prędkość obrotów ślimaka), jak również wpływ kompozycji receptury na wydajność procesu i zużycie energii podczas produkcji pelletów z surowców ziemniaczanych oraz produktu typu multigrain. Wydajność procesu ekstruzji $(Q)$ wyznaczano przez określenie masy produktu uzyskanego w określonym czasie dla wszystkich przygotowanych mieszanek surowcowych oraz zastosowanych parametrów procesu, natomiast jednostkowe zapotrzebowanie energii zostało określone przy użyciu wskaźnika SME (ang. specific mechanica energy). Uzyskane wyniki pozwalają stwierdzić, że poziom dowilżenia mieszanek surowcowych miał większy wpływ na wydajność i energochłonność procesu ekstruzji niż zmiana prędkości ślimaka podczas wytłaczania. Wydajność procesu wzrastała wraz ze wzrostem wilgotności mieszanki, natomiast zaobserwowano spadek zapotrzebowania energii mechanicznej. Zastosowanie zróżnicowanych receptur surowcowych również wpłynęło na wartości $Q$ i $S M E$ wyznaczone podczas badań. Mniejszą wydajność oraz większe $S M E$ odnotowano przy zastosowaniu mieszanki typu multigrain.

Słowa kluczowe: ekstruzja, pellety, ekstrudat, multigrain, wydajność, $S M E$ 